\title{
European Commission from its Establishment and Forecast in the European Constitutional Treaty
}

\author{
Enertila Bekteshi \\ Instituti i Studimeve Europiane, UT \\ Psychologist, QST, Tirana \\ Email: benertila@hotmail.com
}

Doi:10.5901/ajis.2016.v5n3p201

\begin{abstract}
The aim of this work is to show, a brief discription of European Commision, basing in thw respective Albanian and foreing literature. The European Union today presents itself the most important economic and political structure in the continent of Europe, being attractive for other countries, not yet part of it, which aim to be members of European Union with full rights. This is the main aim of our country today, Albania. For this reason, its important to know, how does European Union work, how do its institutions operate, how do the member countires cooperate with each other and of course, which are the criteria and challenges that nomember ccountries have to face with. This si a big help for this group of countires, to put them in the right path to European Union.
\end{abstract}

Keywords: Commission, member, criteria, challenge, help.

\section{Introduction}

The Paris Treaty founded the High Authority as a collegial body assigned upon common agreement of the member countries' governments comprised of 9 members assigned for 6 years and giving the following competencies:

The executive power and its members were obliged to no be influenced by the positions of the countries they represented, which obligation included the member countries as well, to not interfere in the decisions undertaken by the High Authority through their members.

The administrative power which issued acts of mandatory character for the member countries either for the Community or the enterprises running their activity in the coal and steel area. Freedom of expression, decision making, and the right of issuing recommendations, (article 14 of the treaty\}.

The above mentioned competencies gave to the High Authority all the opportunities to fulfil its primary obligation which was the realization of the treaty objective. Initially, the objective (Robert Schuman, 2002,pg.55) was the economic improvement in terms of the directions mentioned in the treaty as follows:

- Modernization of production and improvement of its quality, supply with the same conditions of the French market and of the other member countries of the treaty,

- common export,

- equalization and improvement of living conditions of workers in the these industries.(Robert Schuman,2002,,f.134)

The decisions were taken upon the majority of its members. The Treaty establishing the Economic Community placed the Commission in the position of a supranational institution which of course offered great warranties of autonomy toward the member countries although of small deliberative power. The Commission was comprised of 9 members chosen upon agreement by the governments of the member countries such as: France, Germany, Italy with 2 members each; Belgium, Netherlands, Luxembourg with 1 member each. The assignment was made for 4 years, but assignment from the governments meant "less independence" for the Commission. The Treaty establishing the Economic Community gave various powers, and among them was also the executive power. Essentially, the Commission was a supporter to the activity of the community. The President of the Commission was assigned by mutual agreement of the governments of the member countries in the Treaty establishing the Economic Community and then approved by the European Parliament. The Treaty provided for the Commission three main functions: 1) the control of implementing the policies, 2) introduction of the Community in the negotiations of trade with the third countries, 3) proposal of new policies as a very important function. In the Convention signed in Brussels on April 8, 1965 was founded the Merger Treaty of executive 
powers of the European Communities, replacing High Authority, the Treaty establishing the Economic Community and the Euratom with one unique Commission. The unique Commission was assigned upon common agreement from the governments of the member countries. It was comprised of at least one representative for each member country. The governments' decision should have been unanimous and therefore, although each country appointed by itself its own candidates, their assignment depended on the consent of the other member countries. (Stefan Geroge and lanBache,2001,pg.89,90). The Treaty predicted that the Commission should be comprised of members chosen based on their general competencies offering any warranty for independence. The Commission was defined as a collegial authority and of collective responsibility, (article 10). Also, in article was stated that the Commission's members functioned in "full independence for the interest of the Communities" and obliged them to not accept instructions from any government or non governmental organization and also to not undertake any action which is incompliant with their functions. At the same time, the member countries were obliged to respect the independence of the Commission and to not have any impact their members during their assignment, ( article 232). In case this obligation is not fulfilled, ECJ may declare the dismissal of the Commission's members or losing the pension right. This article is as well expressed on the honesty and delicacy in the functions carried out later on by the commissioners when they shall not be anymore in charge. ${ }^{1}$ Each of these established institutions does not unify at all the competencies of the previous institutions which remain separated. Every special institution through comprised of the same members, sometimes acts as an authority of one community and sometimes as an authority of another community. There is an act which is expressively counted by the treaty, which is the relation on the Community's activities that the Commission should publish each year, at least one month before the Assembly's session. The European Commission participates in the legislative process of EU based on the competencies given by the Treaty establishing the European Community involved in the first pillar of the Treaty of the European Union. The Treaty of the European Union changed s.m.th. either of the vice/presidents which were firstly chosen by the Council of Ministers, whereas now the Commission could choose itself one vice president or two vice presidents among its members. From 1995 the President of the Commission is assigned for 5 years like the other members of the Commission, but prior to the assignment of the new President of the Commission it is necessary the consultation with the European Parliament.

The Treaty of Amsterdam disciplines clearly the segregation of duties between Brussels and member countries thanks to the protocol of subsidiarity. The Commission with the Amsterdam Treaty strengthened its political role, whereas the Treaty strengthened also the competencies of the president of the Commission vis-a-vis commissioners and increased the rights of EP participation in the co-decision-making procedure. Furthermore, the Treaty inserted the most fruitful decision-making procedures for CST and JHA (Treaty of the European Union, Title VI and Treaty establishing the European Community, Title IV). However it failed to encompass the essential institutional reforms for two very important cases

(i) weighting of votes regarding the extension of majority voting and (ii) the composition of the Commission. Both cases were postponed by the Conference to be treated in the 'Protocol for the Institutions with the Perspective of European Union Expansion'.

From March 1st, 2000 with the adoption of the white book on the administrative reform, the European Community marks the effective start of the reform process of its internal functioning for a more efficient and modern operation, being thus prepared for the biggest expansion in its history with 10 new countries. (Milo Paskal, 2002,pg.333). Certain changes require modifications of the legislation which should be made by the Council and the Parliament, like the new financial regulation approved in June 2002 (reform in the community budget etc.). Main reforms defined by the European Commission from year 2000 are:

- A new planning cycle for the strategy and program estimating the necessary human resources for developing the targeted activities following the defined priorities synchronized with the balance sheet process. The basis for the elaboration of preliminary budget project is a policy that should be made by the President of the Commission who gives general directives for the annual political strategy. Such strategy should contain the programmed objectives, the proposed policies and various sources.

- A strategic planning and central programming service which should prepare the debate on the annual political strategy, guarantee a correct application and promote a result-oriented direction.

- An informative system helping in defining the direction applied in the external service and European Development

${ }^{1}$ The case of the former commissioner Martin Bangemann to whom was proposed a very important role in Multinational Corporation, after the mandate it was discussed a lot in the institutions of the Community. 
Fund.

- A program of training and awareness on a management based on activities. ${ }^{2}$

Prior to the entry into force of the Treaty of Nice, the Commission was assigned upon a common agreement from the governments of the member countries. The institutional reform proposed in Nice aimed, among others, the further strengthening of the Commission as an authentic executive within EU. In the protocol of EU expansion annexed to the Treaty, article 4 stated that from January $1^{\text {st }}, 2005$, the Commission will have one representative for each member country. This measure was taken in frame of further expansion of the European Union. Therefore, the size of a country or territory would not have any impact on the number of commissioners, meanwhile the reforms of the Treaty of Nice in connection with the European Commission, which were decided to be implemented from January $1^{\text {st }}$, 2005, would include:

The composition of the Commission. Every member country will have only one representative in the European Commission. The assignment of commissioners will be made with the consent of the member countries upon the Council's decision which will take decision by qualified majority.

After year 2007 when the member countries will be 27, the European Council will decide for the exact number of the Commission's members. The composition will be less than 27 members which is the general number of the member countries. The member will be selected by rotation. Thus, in certain periods not all the countries will be represented in the European Commission.

\section{Change of procedures for the selection of the President of the Commission}

Two proposals have been submitted for this issue: a. at the beginning, it was the European Council deciding for this and then this assignment was approved by the European Parliament. It was used the qualified majority voting process. $\underline{b}$. The President of the Commission used to be selected from the Parliament upon proposal of the European Council or directly from the people of the member countries of EU (the proposal was made by Mr. Fischer, Minister of Foreign Affairs of Germany) (Zaganjori Xhezair, pg.21). The President of the Commission was decided to be assigned based on a new procedure; "The Council gathered with the Heads of States or governments decide with qualified majority the person who will be assigned as the President of the Commission" (article 214). Such design was approved by the European Parliament as well.

Increase of decision-making competencies of the President of the Commission, such as:

- the right to decide on the internal organization of the Commission;

- the right of making the division or re-division of the commissioners' portfolios;

- the right of assigning the vice presidents of the Commission.

The Constitutional Treaty provides the European Commission comprised of 15 commissioners with the right to vote. Also, it will be used the rotation period in order that the countries will vote with their commissioners. The small countries did not support such idea but however required the formula "one country - one vote".

The first Commission appointed based on the Constitution will have one commissioner for each member country. By the end of the mandate, the number of commissioner will be $2 / 3$ of the member countries, and despite this The European Council decided unanimously to vote according to a system to be defined later on, but however will be based on the equalization principles of the member countries and reflection of their demographic weight.

The Constitutional Treaty provides as well the creation of the post of the Minister of Foreign Affairs of the Union which would unite the current functions of the Commissioner with the External Relations and High Representatives for the Foreign Affairs and Security Policy. In the European Constitution the appointment of the President of the Commission and the permanent role of the President of the European Council is given by the European Parliament only. Such proposal was not accepted. In fact, the Constitution in article 21 does not define for the President of the European Council any conflicts of interest with the mandate of community level, but there is in incompliance at national level.

\section{Main Functions of the Commission}

The Commission with its monopoly on the legislative initiative, is the only body that can make proposals on the legislative acts of the Community. 
Furthermore, it is the executive body of the European Union that guarantees the execution of Council's decisions in different issues of the community policy (agriculture, research, technology, development aid, regional policy etc.).

The Commission:

- manages the budget, prepares the annual budget draft of EU to be discussed in the Council of Ministers and European Parliament.

- is a guard of treaties. (Jurisprudence of the Court of Justice).

- is the guarantor body of competition and supervises the application of anti-trust policy.

- takes framework decisions in this area.

- supervises the countries to fulfil their obligations resulting from the community treaties and community rights.

- in case of potential violations, it may open a special procedure requiring a warning letter and may be followed by a motivated through and finally will end in front of the judge of the Court of Justice (Zanobetti Allessandra,2004, pg.7).

- $\quad$ represents the European Union in the relationships with the thirds.

- answers collectively in front of the European Parliament.

- $\quad$ has the general power of the recommendations. This power is executed in the cases provided by the treaty or when deemed appropriate by the Commission.

- $\quad$ has the power in taking decisions and participates in the formulation of acts of the Council and European Parliament under the terms provided by the treaty.

Stating that the Commission is the only one proposing the legislation does not imply that it works for the legislative proposals in practice, but consultation is used with the groups of interest, technical experts and representatives of national bureaucracy. However it strictly keeps the right of initiative.

\section{Role of the President}

After the enforcement of Amsterdam Treaty, there is an increase of the role of the Commission President which defined the collegial political orientation. Nice (article 217) strengthens the president's role on the internal organization of the Commission to guarantee the coherence, efficiency and collegiality, expressed for the first time in the treaty. The President gives competencies to the commissioners and may modify separation of duties during the mandate. The President appoints the vice presidents after the prior approval of the college. Each member of the Commission should resign if required by the President after the prior approval of the college.

\section{Commission and the Member Countries}

At first the Commission is seen as a functional body to the member countries. Therefore, the Commission is considered as a secretariat of any other international organization. In this case, the Commission's function is to run the relationships between governments and they may find co-operation agreement with each-other. When agreement take place in the external agenda for cooperation, the member countries find it convenient to delegate some competencies to the Commission. The Commission for the member countries is a reliable source of independent proposals since it carries a technical information and it is a neutral arbiter in case of potential risk between the member countries. Delegation of the proposals' power to the Commission reduces the cost of cooperation and thus diminishing the risk of delayed decisions from a competition "battle" and an unjust final decision. In case of alternative proposals, it might win the majority selection (George Stefan, Bache lan, pg.228-9). However, the delegation of the right to make detailed proposals gives to the Commission a formal secure power. In this viewpoint, the Commission does not establish the directives by which the European Union acts. It helps the member countries to agree in details on what they have decided and in what they want to do regardless of the circumstances, potential source of proposals or closure of cases to facilitate the compromise between the national proposals. Other actors are able to perform such functions and may often use this delegation to incline the member countries toward the objectives not undertaken by them. For the countries it is often difficult to have under control all the case, whereas the Commission owns more information. This is one of the reasons for the delegation of above proposals. At the same time, the member countries have provided the means to have under control the Commission.

Firstly they have established an entire group of committees with national experts to monitor the actions of the Commission. The managing committees which mainly acted in the agricultural policy sector may refer a decision of the Commission in the Council of Ministers for review. 
Secondly (article 230,former article 173) of the Treaty allows complaints to the Court of Justice for the actions of the Commission when an individual or component believes that the Commision has surpassed its power.

\section{Commision is an Autonomous Actor and Executant}

The perspective that the Commission is more than an operator of the member countries is dominating. In fact, the Commission acts and should act autonomously to ensure a leadership policy in the European Union. Advocates of above perspective underline the sources that allow the Commission to do this. The Commission does not passively expect that the member countries require different proposals. The Commission should identify a problem that has started in the governance, express its concern and also should propose a European solution using the unique market program. The Commission uses the right of self-determination initiative to reflect the case as an opposition in the Council of Ministers where it finds the political position of the member countries. It may also play a role in the Europeanisation policy within the governments' agenda. By including internal interests at EU level through such advisory instruments like the committees, the Commission wants to come out with the ides that a case may be treated better at European level. Such initiatives may help the governments of member countries to allow the Europeanisation of the member countries in the sectoral policy and also allow the Commission to use them and if necessary to create international network of producers that will be in the private sector. The Commission make this in the cases of the technology and telecommunication policy. It encourages the industrial users and press in each of these sectors, to oblige the governments to leave the national monopolies and create European market with European rules. The political process is not finished when agreement is achieved for the legislative proposal. The agreement should be still be realized before the policy has a real existence. In other words, the implementation is an integral part of the political process. For many types of the legislative, the primary executants are the governments and the administrators of the member countries. The Commission has a central role in the case of other types of legislation and is also in charge (article 211, former article 155) to ensure that the treaty's provisions and the measures taken by the institutions are applied. Formally speaking, the Commission is responsible to apply the decisions in some processes of the European Union but in any case it carries the main role.

Firstly, in the execution of the common policy of competition including the control of the multinational enterprises. Administration of the international policy is the one less controlled, regarding the prediction of the food aid where the Commission is the only liable of the European Union through in cooperation with other organizations.

Secondly, in the common agricultural policy (CAP) and definition of the fund administration used for this policy.

Thirdly, in the execution of the Council's directives where the Commission has a double role as a guard of treaties to ensure that the directives are combined within the national law and ensure also that they have been applied (George Stefan and Bache lan, pg.232).

\section{Conclusion}

The Commission's role stands at the centre of explanations on the nature and step forward the European integration. It is clear that the debate is made for EU. In case the Commission would be considered as an autonomous actor, the fact that $\mathrm{EU}$ is an intergovernmental organization will normally diminished even more. So far, the Commission has been at the centre of critiques in its role as a manager within the policies of the Community and finances. Whereas the enforcement policy is never in rectilinear movement within the member countries ${ }^{3}$. Therefore, it is hard to achieve the policy goals in an EU inclined to expansion, where the Commission is still dependent by the national governments and administrations. This has made even more difficult the Commission's work. Another aspect is the possibility of EU to make an efficient policy in the enterprising area, to establish some basic criteria of efficiency in connection with the decisions taken and demonstrate capacities to correct the effect of failures. Moreover, the Commission's role in the budget management should be even more obvious. (George Stefan and Bache lan,2002, pg.232).

${ }^{3}$ Another member country may sue another country of violating the obligations under the care of the Commission which has the right to be expressed within 3 months, after this the case goes automatically to the Court. The implementation of the financial instruments is subject of detailed analysis from the Court of Accounts (article 226, former-article 169). 


\section{References}

European Union, Paskal Milo. Publishing House "Albapaper", Tirana 2002.

European Union. Summary of Treaties. Consolidated Version. Publication of the European Center. Tirana 2000.

Politics in the European Union, Stephen George, lan Bache. Oxford, University Press. Publication 2001.

The institutions of the European Union, John Peterson 85 Michael Shackleton. Oxford University Press. Publication 2002.

The Right of the European Communities. Fausto Pocar. Publishing House "Logoreci".Tirana 1995 and 1998.

The European Right, Iva Zajmi. Lectures. Publication 2001. Understanding European Foreign Policy, Brian White.

Guide to the European Union/ Dick Leonard. Publication The Economist. (Eight Edition) printed in Great Britain by Edmundbury Press.

Progetto di Trattatto che Istituische una Constituzione per T Europa. Publication, July 2003.

Robert Schuman. In the name of Europe. Copyright for Albanian publication, publishing house Ora 2002. Copyright fondation Robert Schuman/ Paris.

II diritto deir Unione Europea. Luigi Daniele. Publishing2004. Prof. Bologna University (Italy).

For the Institutional Reform of the European Union, Xhezair Zaganjori. (Lectures)

Allessandra Zanobetti (Instituzioni e Organi UE). Lectures, October 2004.Prof, in Bologna University (Italy).

The European Union and the member States, (Cooperation, Coordination and Compromise), Eleanor E.Zeff, Ellen B.Pirro.Publication Lynne Rienner/Publishers/Boulder London. 2001

The Economics of the European Union and the Economies of Europe, Larry Neal and Daniel Barbezat, Botim Neë York/ Oxford / Oxford University Press 1998.Larry Neal (University of Illinois at Urbana- Champaign), Daniel Barbezat (Amherst College)

U Europe des Communautes, La documentation francaise, Paris 1992. Les noties.

Developments in the European Union. Edited by Laura Cram, Desmond Dinan, Neill Nugent/ First published 1999 by Macmillan Press LTD/ London.

European Union Law. John Tillotsot (Third edition). Printed in Great Britain/ First published in 2000 by Cavendish Publishing Limited.

From Versailles to Maastrihcht, David Armstrong, Lorna Lloyd and John Redmond, First published 1996 by Macmillan Press Ltd, Houndmills, Basingstoke, Hampshire RG21 6XS.

The European Community. M. Donald Hancok and Guy Peters,part six. Botimi ne New Jersey.

L" Europe, L* Etat et la democratic. Paul Manette. Botimi, Editions Complexe, 2000. 